\title{
Rebar Fabrication Process in Both Field Processing and Factory Processing for Adopting Lean Construction
}

\author{
Seok-Heon Yun and Sang-Chul Kim \\ Dept. of Architectural Engineering, Engineering Research Institute, GyeongSang National University, Jinju, South Korea \\ Dept. of Architectural Engineering, Hanbat National University, Daejeon, South Korea
}

http://dx.doi.org/10.5659/AIKAR.2013.15.3.167

\begin{abstract}
Due to increasing competition of construction companies, it is required to optimize the management of construction projects and "lean" concepts are rapidly spreaded in construction industry. Steel work accounts for a large proportion in construction work, and a variety of attempts to efficiently perform steel work has currently made. And since rebar (Engineer-to-Order) can be engineered through design once order is placed, it gives the great impact on construction, thus, entire management is required. The purpose of this study is to present the method to increase the efficiency of field processing method of steel work in terms of lean construction. Once we examine process of steel work and identify the flow, we would like to analyze which processes should be improved through value analysis approach and present the improvement plans. Also, this study examines cases of field processing and factory processing, and it identifies the waste factors in the procurement process. Finally, this study would like to present the result of analysis from the perspectives of value. The rebar delivery process is divided into several steps and the duration of every step is surveyed. Using duration data, VAT (Value added time) can be calculated for analyzing the efficiency of the process.
\end{abstract}

Keywords: Lean Construction, Rebar, SCM (Supply Chain Management)

\section{INTRODUCTION}

A very wide variety of materials is being used in construction, and these materials can be largely divided into four types: MTS (make-to-stock), in which the material is made in a factory in advance and is immediately supplied to the required construction; ATO (assemble-to-order), in which the material is ordered by those who need it, and parts are assembled and supplied; MTO (maketo-order), in which the material is produced and supplied once an order is placed; and ETO (engineer-to-order), in which the material is engineered through the design process once an order is placed. Among these materials, as the ETO material can be engineered through design once an order is placed, it has a great impact on construction; thus, full management is required.

Among the ETO materials, the major materials are bar, steel, and PC (precast concrete) members. As domestic construction mainly uses the in-site bar concrete construction method, the procurement

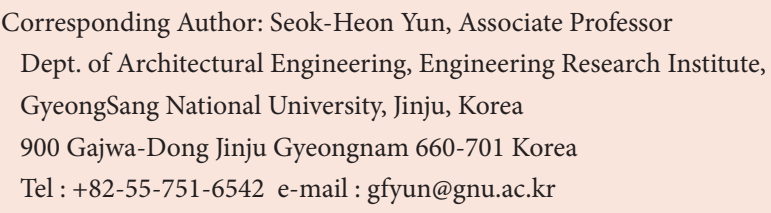

This study was partly supported by NRF under Grant No. 2011-001585

This is an Open Access article distributed under the terms of the Creative Commons Attribution Non-Commercial License (http://creativecommons. org/licenses/by-nc/3.0/) which permits unrestricted non-commercial use, distribution, and reproduction in any medium, provided the original work is properly cited. of steel is the construction task that has a very important impact on the construction work.

Once the research team examines the process of steel work and identifies the flow, it analyzes which processes should be improved through the value analysis approach, and presents the improvement plans in terms of lean construction. Currently, field processing and factory processing are utilized parallel to each other, but the criteria for determining which is more efficient have not yet been presented. Therefore, in this study, cases of field and factory processing were examined, and the waste factors in the procurement process were identified. Finally, in this paper, the results of the analysis from the perspective of value are presented.

To achieve the above, the research team classified the materials used in construction work based on the process, and investigated the definition of waste factors in the process of the production and procurement of materials, and in the entire process of steel work. Thereafter, the waste factors in the processes by step were classified into VAA (value-adding activity) and NVAA (non-value-adding activity), and were analyzed. The improvement plans of the field processing methods focused on the analyzed factors are presented herein.

The research team then selected a case field to analyze the courses ranging from the order of the steel work to the processing and assembly of the bars, and examined the process by stage. The time and personnel used for each stage were also examined. The waste factors in each stage were classified into VAA (valueadding activity) and NVAA (non-value-adding activity), and were analyzed. Finally, the characteristics of and difference between the processing methods by stage were analyzed, and the differences are presented herein. 


\section{LITERATURE REVIEW}

\section{1) Past studies}

As steel work is a major process of construction work and consists of complex processes, various studies on the improvement plans for such process have been conducted. The following table shows a number of related cases and an overview of their steel work improvement plans, and summarizes the studies about the methods of field and factory processing related to this study.

Table 1. Literature review

\begin{tabular}{|c|c|}
\hline Authors & Main contents \\
\hline $\begin{array}{l}\text { Hoon Hui Cho, } \\
\text { Gyeong In } \\
\text { Kang (1996) }\end{array}$ & $\begin{array}{l}\text { Analysis of the condition of bar processing work and } \\
\text { the loss rate of bar processing and field processing bar } \\
\text { targeting field bar processing construction in domestic } \\
\text { apartment }\end{array}$ \\
\hline $\begin{array}{l}\text { Moon Jeong } \\
\text { Moon (2001) }\end{array}$ & $\begin{array}{l}\text { Purpose is to increase the efficiency of construction } \\
\text { production system by minimizing non-value creation } \\
\text { work and optimizing the inventory between tasks. Value } \\
\text { analysis by applying lean principle about field processing } \\
\text { assembly of bar assembly process in framework. }\end{array}$ \\
\hline $\begin{array}{l}\text { Gwang Hui } \\
\text { Kim et al. } \\
(2002)\end{array}$ & $\begin{array}{l}\text { Problems of entire process from quantity take-off step to } \\
\text { processing and assembly are derived and improvement } \\
\text { plans using a computerized system is presented. }\end{array}$ \\
\hline $\begin{array}{l}\text { Jin Gyu Ju } \\
(2003)\end{array}$ & $\begin{array}{l}\text { Establishment of a work model for efficient construction } \\
\text { management for steel work } \\
\text { Establishment of a model to improve bar productivity } \\
\text { through work sampling and simulation techniques }\end{array}$ \\
\hline $\begin{array}{l}\text { Wu Yeol Park, } \\
\text { et al. (2004) }\end{array}$ & $\begin{array}{l}\text { Status and problems of steel work targeting Estimate } \\
\text { department and construction field are analyzed and } \\
\text { improvement plans are presented } \\
\text { It is classified into calculation of quantity of bar, order } \\
\text { and purchase of bar materials, process of bar and } \\
\text { arrangement stages and the survey is conducted. }\end{array}$ \\
\hline $\begin{array}{l}\text { Wu Yeol Park, } \\
\text { et al. (2005) }\end{array}$ & $\begin{array}{l}\text { Development of steel information integration } \\
\text { management system which can integrate and manage } \\
\text { information on steel in bar processing factory }\end{array}$ \\
\hline $\begin{array}{l}\text { Hoon Hui Cho, } \\
\text { et. Al (2007) }\end{array}$ & $\begin{array}{l}\text { Standardization of steel processing shape, } \\
\text { computerization of production of documents related to } \\
\text { steel and development of system of bar material tracking } \\
\text { is proposed for activation of steel factory processing }\end{array}$ \\
\hline
\end{tabular}

\section{2) Classification of materials by procurement process}

In production management, products are generally classified into MTS (Make-to-stock), ATO (Assemble-to-order), MTO (Make-toorder) and ETO (Engineered-to-order) (Wortmann et al. 1997, Handfield 1995).

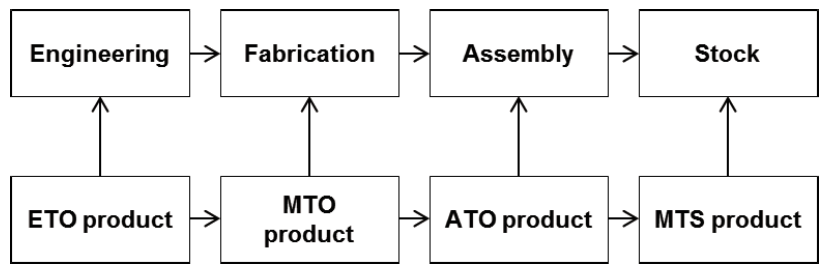

Figure 1. Classification of material

MTS products are procured for the customer's orders from the inventory with completed products, and the inventory of products is made through prediction. Therefore, even if a product's manufacturing cycle time is very long, the queuing time for the customers' orders is very short. In the case of ATO products, the option or other parts are managed in the inventory. When a customer's order is placed, the product assembly is started. Compared with MTO, the inventory cost increases, but the queuing time can be reduced more. In the case of MTO products, while the inventory is maintained at the level of raw materials, the product is produced when a customer's order is placed (Handfield, 1995, pp. 5-7). In the case of ETO products, if a customer's order is placed, it goes through engineering, production, and procurement.

Table 2 shows the characteristics of each type of product, and the related cases.

\section{3) Definition of waste in the process of material production}

a) TFV (Transformation-Flow-Value) Theory

According to TFV theory, design, control and improvement required for the production activities are made by only integration of transformation, flow and value concept (Koskela 1999).

In the concept of flow, the activity of production consists of inspection, waiting, transport, and transformation. As inspection, waiting, and transport are not value elements, they should be reduced as much as possible. The major causes of waste

Table 2. Characteristics of production management by types of products (Wortmann et al. 1997)

\begin{tabular}{|c|c|c|c|c|c|}
\hline Focus & Product & Work flow & Resource & Product & Product \\
\hline Kind of products & ETO & MTO & MTO & ATO & MTS \\
\hline Case & $\begin{array}{l}\text { Bar, } \\
\text { Facility machine }\end{array}$ & $\begin{array}{l}\text { Pre-fabricated electrical } \\
\text { outlet }\end{array}$ & $\mathrm{PC}$ & Windows, doors & Bricks, bolt \\
\hline Interest of top manager & $\begin{array}{l}\text { Customer } \\
\text { Order contract }\end{array}$ & $\begin{array}{l}\text { Process } \\
\text { Innovation }\end{array}$ & Volume & Product innovation & Sales \\
\hline Uncertainty of work & Product specification & Production scale & Work preparation & Mixing of order & $\begin{array}{l}\text { Product } \\
\text { life cycle }\end{array}$ \\
\hline Complexity of work & Engineering & Final production step & Parts manufacturing & Assembly & Physical sale \\
\hline $\begin{array}{l}\text { Interest of middle } \\
\text { manager }\end{array}$ & Business management & Quality management & $\begin{array}{l}\text { Subcontracting, place of } \\
\text { business management }\end{array}$ & $\begin{array}{l}\text { Major production } \\
\text { schedule, customer } \\
\text { order contract }\end{array}$ & Inventory management \\
\hline $\begin{array}{l}\text { Interest of information } \\
\text { system of PM }\end{array}$ & $\begin{array}{l}\text { Product engineering } \\
\text { support }\end{array}$ & Progress management & $\begin{array}{l}\text { Production engineering } \\
\text { support }\end{array}$ & $\begin{array}{l}\text { Materials supply and } \\
\text { order entry support }\end{array}$ & $\begin{array}{l}\text { Forecasting and } \\
\text { inventory management } \\
\text { support }\end{array}$ \\
\hline Characteristic of IS & Productive solution & Workflow management & Reference solution & Rule & Decision support \\
\hline
\end{tabular}


are (1) overproduction of products; (2) waiting for the inventory for future processing or consumption; (3) unnecessary production; (4) unnecessary moving of people; (5) unnecessary moving of products; (6) waiting of employees until a higher work is completed; (7) product defects; and (8) production of products and services that do not meet the users' demands.

The main purpose of the concept of value is to create the best possible value for the customers based on the customers' demands. According to the results of this study, more than $50 \%$ of the design involves non-value-added time in the construction area (Freire \& Alarcon, 2000). From this point of view, the efficiency of the construction work can be improved if waste factors such as waiting and re-design from the step of the design process are reduced.

Much of the time in the production process is used for waiting. For example, there is a need to wait until the entire production line is completed due to the delay in the production line. Waiting for the process may occur due to improper synchronization.

b) Value-adding activities and non-value-adding activities

All the works required for production can be divided into valueadding activities (hereafter, "VAAs") and non-value-adding activities (hereafter, "NVAAs"). To minimize the NVAAs, the value should be more specifically defined. Koskela (1992) defined the production process as involving moving, waiting, processing, and inspection, as shown in the figure below.

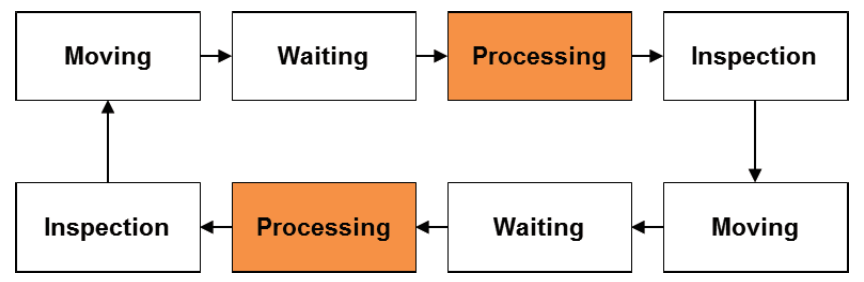

Figure 2. Production process

As shown in the table below, only processing creates the added value as a VAA, and moving, waiting, and inspection create waste as NVAAs.

Table 3. Definition of value creation

\begin{tabular}{c|c}
\hline & Value creation \\
\hline Processing & VAA \\
\hline Moving & NVAA \\
\hline Waiting & \\
\hline Inspection & \\
\hline
\end{tabular}

c) Analysis of value

The main purpose of the concept of value is to create the best possible value for the customers based on their demands. Therefore, measurement of the requirements and resources is needed to measure the value. A variety of quantification methods are currently being developed based on this. The main purpose of most studies on value is to develop a "value function," to apply the cost of the function or other measurement standards, and to compare them.

VAT can be calculated as the percentage of labor time used for the actual-value work to the total labor time required for the entire procurement process. In other words, the actual time spent on work and the total lead time required in the procurement process are compared. The VAT can be calculated using the following equation:

$$
\mathrm{VAT}=\mathrm{LH} /(\mathrm{W} \times \mathrm{LT}) .
$$

Here, $\mathrm{LH}$ is the sum of the labor time spent on each work in the step, and $\mathrm{W}$ is the number of workers working in the step at the same time. In addition, LT is the total lead time in the step. For example, the LH of the design time of the parts is 916 hours, and the number of workers (W) is 3 . If the total preparation time (LT) is 880 hours, the VAT becomes $35 \%$. As the VAT is higher, the percentage of value work becomes higher.

\section{BAR CONSTRUCTION PROCESS}

\section{1) Bar construction process}

General construction companies take off the bar quantity to make up a working budget after obtaining the order. The estimated quantity is divided by bar size and floor, and it is totaled in the weight. In general, it does not take into account the shape and length of the bar actually used for the construction. Therefore, uncertain information is created in the initial stage to create information related to the bar materials, and procurement management is performed based on this information.

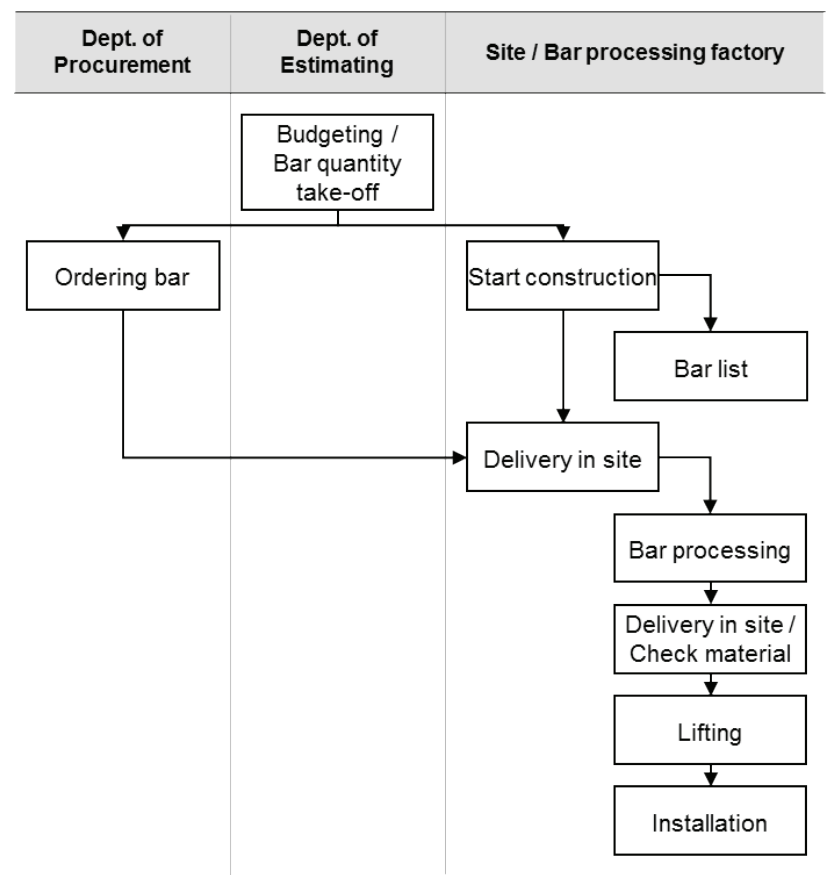

Figure 3. Steel work process

Bar subcontracting creates a shop drawing after obtaining the order of bar construction, and calculates the quantity of the bar consumed by shape and size, based on the drawing. It creates a bar list and bar schedule and processes the bars using these data. 
Once the bar processing is completed, the bars are transported to each installation site and then assembled in the designated place by the steel workers. Once the arrangement is completed, the quantity of the constructed bars is identified based on a certain period of time (typically a month), and the payment given to the subcontractors is determined by comparing the quantity created upon budgeting with the quantity of the bars introduced to the field.

It is shown that an order is placed 7.2 days ahead of introduction to the field on average. It is desirable to place an order 8.6 days ahead of introduction on average, for proper factory processing.

\section{2) Field and factory processing of bars}

The processing of bars can be classified into field processing and factory processing. The differences between these two involve the processing of the shapes of the bar materials and their processing in the factory and introduction to the field.

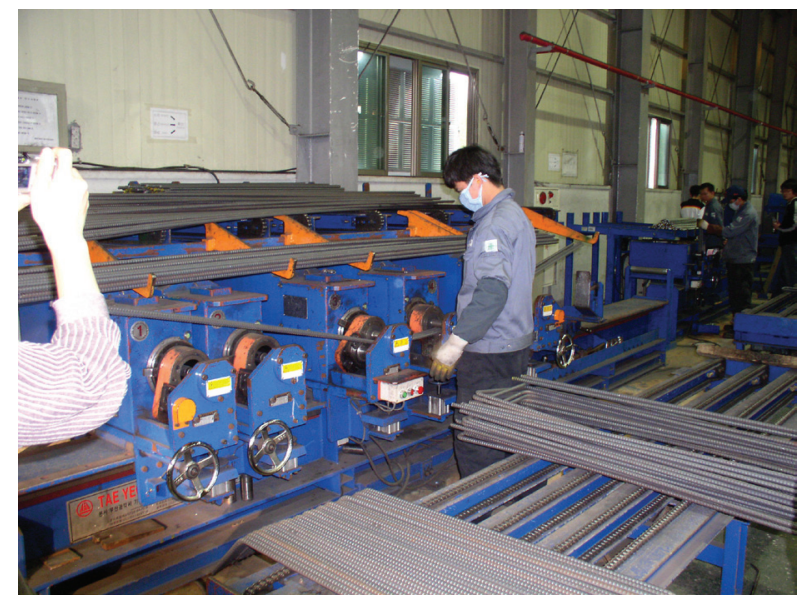

Figure 4. Field processing of rebar

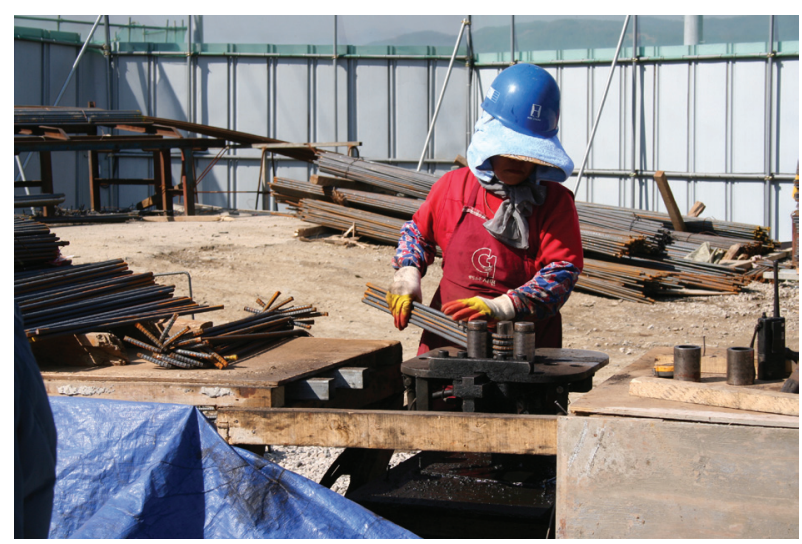

Figure 5. Factory processing of rebar

The table below (Kim, 2006) compares field processing and factory processing, and shows that the factory processing of bars is more efficient in various aspects. The field processing of bars, however, is widely used because of the imperfection of the factory processing of bars, the uncertainty of the drawing, the frequent changes in the orders, and the lower field labor cost.
Table 4. Comparison between factory and field processing

\begin{tabular}{|c|c|c|}
\hline & Factory processing & Field processing \\
\hline Amount & 10,000 ton & 10,000 ton \\
\hline $\begin{array}{l}\text { Processing } \\
\text { unit cost }\end{array}$ & $38,000 /$ ton & $25,000 /$ ton \\
\hline $\begin{array}{l}\text { Assembly } \\
\text { unit cost }\end{array}$ & $145,000 /$ ton & $145,000 /$ ton \\
\hline Loss & $3 \%$ & $8 \%$ \\
\hline $\begin{array}{l}\text { Additional } \\
\text { material } \\
\text { cost }\end{array}$ & None & $222,500,000$ \\
\hline $\begin{array}{l}\text { Additional } \\
\text { processing } \\
\text { cost }\end{array}$ & None & $85,000,000$ \\
\hline Total & $\begin{array}{c}183,000,000 \\
(183,000 / \text { ton })\end{array}$ & $\begin{array}{l}2,007,500,000 \\
(200,750 / \text { ton })\end{array}$ \\
\hline $\begin{array}{l}\text { Additional } \\
\text { cost }\end{array}$ & None & $177,500,000$ \\
\hline Etc & None & $\begin{array}{l}\text { 1. Yard and processing } \\
\text { place } \\
\text { 2. Stocking fee } \\
\text { 3. Electronic fee }\end{array}$ \\
\hline
\end{tabular}

\section{3) Waste factors in the steel work process}

The general waste factors that may occur in field processing are as follows:

- in-site storage of unnecessary bars, and waiting for bars (WIP);

- moving of unnecessary materials (bars), personnel, and equipment;

- additional storage yard in-site, negligence in materials management, and material loss;

- occurrence of inherent variation due to many WIPs;

- difficulty of quality management and degradation of the arrangement precision;

- inaccuracy of the shop drawings and bar list;

- low productivity due to personnel processing, and wage rise due to the lack of personnel; and

- construction progress due to result-centered thinking.

Value analysis was conducted to analyze the waste factors in the method of field processing assembly in steel work. Steel work was divided into VAAs and NVAAs to analyze the waste factors occurring in each step based on the inspection format. Based on the process presented in Figure 3, research was conducted, and the following results were obtained: 
Table 5. Analysis of field processing assembly value

\begin{tabular}{|c|c|c|c|c|}
\hline & \multicolumn{2}{|l|}{ Process } & Flow & $\begin{array}{l}\text { Presence } \\
\text { of Value }\end{array}$ \\
\hline 1 & \multicolumn{2}{|l|}{ Bar supply } & moving & NVAA \\
\hline 2 & \multicolumn{2}{|c|}{ Inspection (Builder/Subcontractor) } & Inspection & NVAA \\
\hline 3 & \multicolumn{2}{|c|}{ storage in site } & moving & NVAA \\
\hline 4 & \multicolumn{2}{|c|}{ Storage in open storage year } & waiting & NVAA \\
\hline 5 & \multicolumn{2}{|l|}{ Loading } & moving & NVAA \\
\hline 6 & \multicolumn{2}{|c|}{ Minor transport } & moving & NVAA \\
\hline 7 & \multicolumn{2}{|c|}{$\begin{array}{l}\text { Moving to processing site (Bar } \\
\text { processing plate) }\end{array}$} & waiting & NVAA \\
\hline 8 & \multirow{9}{*}{ Processing } & Moving to bar cutting & moving & NVAA \\
\hline 9 & & Cutting & processing & VAA \\
\hline 10 & & $\begin{array}{l}\text { Pile up of cutting } \\
\text { processing products }\end{array}$ & waiting & NVAA \\
\hline 11 & & $\begin{array}{l}\text { Moving to bar } \\
\text { processing plate }\end{array}$ & moving & NVAA \\
\hline 12 & & Moving to bar cutting & moving & NVAA \\
\hline 13 & & bar bending & processing & VAA \\
\hline 14 & & $\begin{array}{l}\text { Pile up of bar bending } \\
\text { processing products }\end{array}$ & waiting & NVAA \\
\hline 15 & & Bar bundling & processing & VAA \\
\hline 16 & & Bar labeling & processing & VAA \\
\hline 17 & \multirow{2}{*}{ Lifting } & Lifting preparation & waiting & NVAA \\
\hline 18 & & Lifting/ Unloading & moving & NVAA \\
\hline 19 & \multirow{3}{*}{ Assembly } & $\begin{array}{l}\text { Assembly preparation } \\
\text { (waiting) }\end{array}$ & waiting & NVAA \\
\hline 20 & & Assembly & processing & VAA \\
\hline 21 & & Inspection & Inspection & NVAA \\
\hline
\end{tabular}

\section{CASE STUDY}

In this study, six case sites were selected, and the time and amount of materials for each work in all the processes, ranging from the selection of a subcontractor for the steel work to the insite installation, were analyzed. The table below gives an overview of the case fields selected in this study, which were selected focusing mainly on multi-unit residential projects.

Table 6. Case sites overview

\begin{tabular}{c|l|c|c}
\hline & Type & $\begin{array}{l}\text { Bar } \\
\text { processing }\end{array}$ & $\begin{array}{l}\text { Steel amount } \\
\text { in typical floor (ton) }\end{array}$ \\
\hline A & Residential (tower) & Field & 42 \\
\hline B & Residential & Field & 34 \\
\hline C & Multi residential & Factory & 50 \\
\hline D & Residential & Field & 49 \\
\hline E & Residential & Factory & 55 \\
\hline F & Multi residential & Factory & 73 \\
\hline
\end{tabular}

In this study, the entire process of steel work was simplified into seven steps, as shown below, and the efficiency of the work was investigated by step. In addition, the research team came up with a data investigation sheet in a certain format for the field data for each case, with cooperation from the person in charge of the construction. The research team examined the quantity of the materials introduced to the field, and the process table, and identified the meaning of data and accuracy in the data investigation sheet. A slight error can occur, however, due to the different ways of planning and managing the construction of each field, the concept of used quantity, and the various conditions of the field.

Table 7. Process to be examined by steps in this study

\begin{tabular}{|c|c|c|}
\hline \multicolumn{2}{|l|}{ Course in each step } & Presence of value \\
\hline \multicolumn{2}{|c|}{ Selection of subcontractor and contract } & NVAA \\
\hline \multirow{2}{*}{$\begin{array}{l}\text { Creation of shop } \\
\text { drawing }\end{array}$} & Initial amount & VAA \\
\hline & $\begin{array}{l}\text { Amount for one typical } \\
\text { floor }\end{array}$ & VAA \\
\hline \multicolumn{2}{|c|}{ Bar processing (1 typical floor) } & VAA \\
\hline \multicolumn{2}{|c|}{ Delivery in site (1 typical floor) } & NVAA \\
\hline \multicolumn{2}{|c|}{ Bar check (1 typical floor) } & NVAA \\
\hline \multicolumn{2}{|c|}{ Moving to lifting point (1 typical floor) } & NVAA \\
\hline \multicolumn{2}{|l|}{ Installation } & VAA \\
\hline
\end{tabular}

\section{1) Selection and contracting of a subcontractor}

In most cases, the selection of a subcontractor is made through the headquarters, and it usually takes an average of 31 days from the beginning to come up with an agreement. A certain period of time is spent on the course from the selection to the contracting of a subcontractor, regardless of the size of the business. The time spent on each case is shown in the following figure.

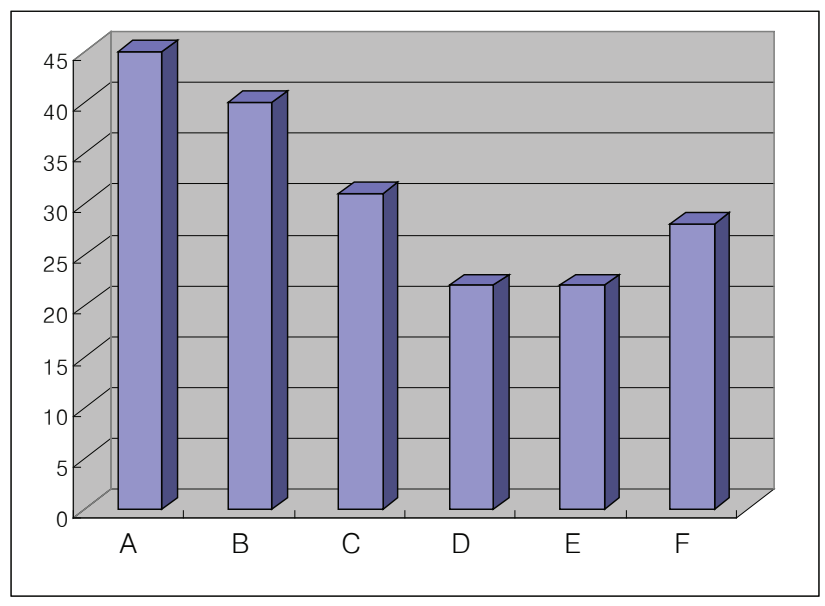

Figure 6. Selection of subcontractor and contract time

The selection and contracting of a subcontractor is an indispensable course, but it is a non-value work in the concept of lean construction. It is thought that time reduction is needed through the improvement of such course. 


\section{2) Creation of a shop drawing}

The creation of shop drawings is carried out according to the progress of the construction. In the case of the creation of shop drawings in the early stage, it takes such a long time to understand the drawings, and to develop the required skill. In the case of a typical floor, however, in which each floor is repeated, two to three days are required. Compared with the creation of shop drawings in the early stage, only about $20 \%$ of the time is needed. In addition, in the case of factory processing, as it is carried out depending on the special personnel or system creating the shop drawings, it takes an average of 9.6 days. On the other hand, in the case of field processing, it may take 12.7 days, three days more than in factory processing.

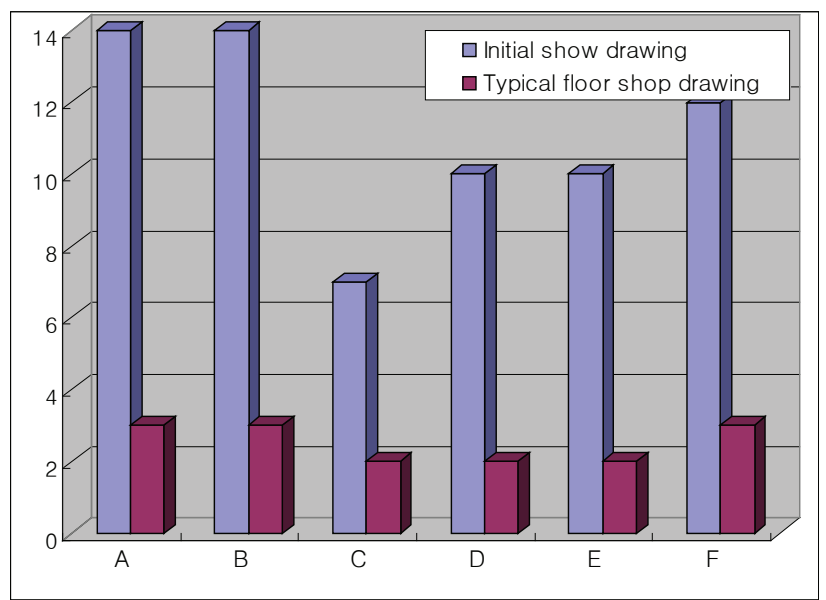

Figure 7. Creating time of shop drawing

3) Procurement of bar materials

With regard to the entire process, ranging from the creation of shop drawings to in-site assembly and installation, the time spent on each step for one typical floor was investigated.

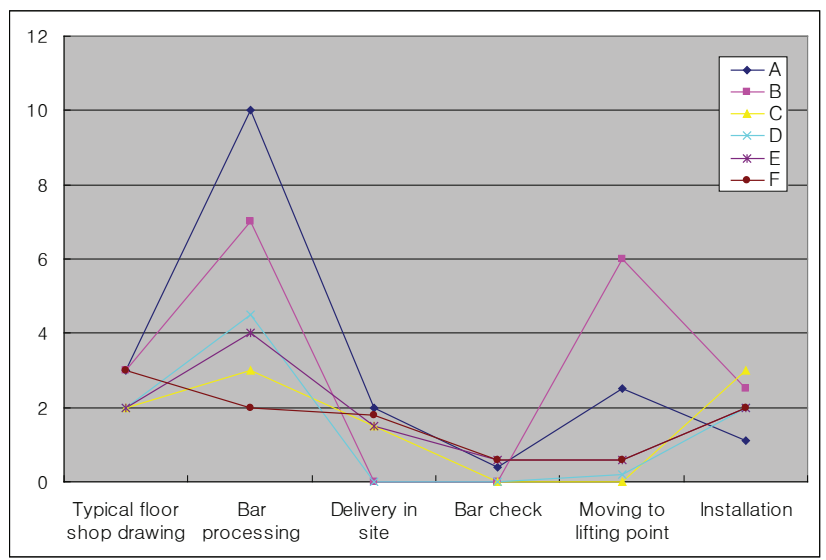

Figure 8. Consuming time in each step

In the above figure, the time spent on each step for the cases can be seen. There are slight deviations due to the situations and characteristics of the field.

\section{4) Comparison of factory processing and field processing}

The time used in the three fields in which bar factory processing is applied and in the three other fields in which field processing is applied was analyzed by step. The results are shown in the figure below.

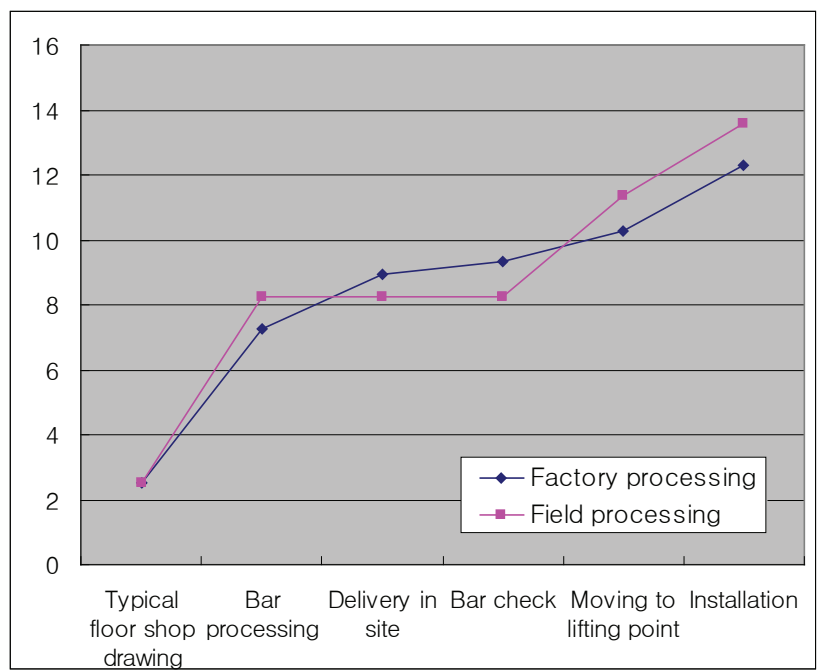

Figure 9. Consuming time between factory and field processing of bar

As shown in the figure, there is no significant difference in the creation of shop drawings. In bar processing, however, factory processing was carried out efficiently. In the case of factory processing, some time was spent on additional processes, such as in-site delivery and bar check. On the other hand, in the case of field processing, it took two to three days on average to complete the process from field processing to moving to the installation site.

In this study, in-site delivery, bar check, and moving to the lifting point are defined as NVAAs. Field processing and factory processing are compared in the figure below.

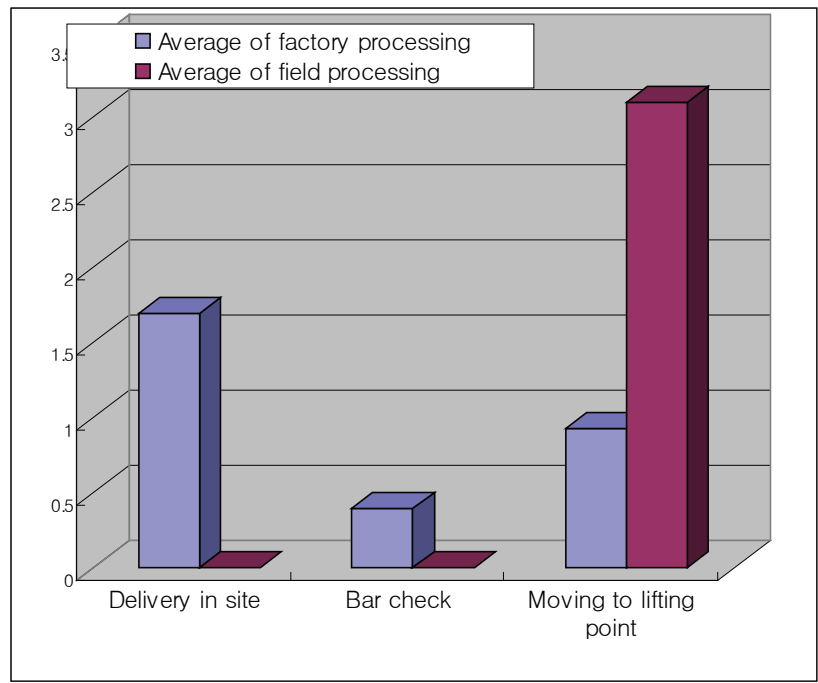

Figure 10. Comparison of NVAA in factory and field processing of bar

As shown in the figure, factory processing needs a 0.5 - to 1.5 day NVAA for in-site delivery, bar check, and moving to the lifting 
point. On the other hand, field processing needs a queuing time of three days on average from processing to moving to the installation site. In other words, it has an NVAA. Based on the interviews from the case studies, the waste factors and improvement plan in the steel work are shown in the following table.

Table 8. Problems in each step on rebar processing

\begin{tabular}{|c|c|c|}
\hline & Field processing & Factory processing \\
\hline $\begin{array}{l}\text { Selection of } \\
\text { ubcontractor } \\
\text { and contract }\end{array}$ & Simplify the process & - Simplify the process \\
\hline $\begin{array}{l}\text { Creation of } \\
\text { shop drawing }\end{array}$ & $\begin{array}{l}\text { Improve productivity } \\
\text { through automating } \\
\text { creation of shop } \\
\text { drawing }\end{array}$ & $\begin{array}{l}\text { - Need to check drawing } \\
\text { due to drawing error } \\
\text { or lack of detailed shop } \\
\text { drawing } \\
\text { - Need to make } \\
\text { standardization of bar } \\
\text { processing }\end{array}$ \\
\hline $\begin{array}{l}\text { Bar } \\
\text { processing }\end{array}$ & $\begin{array}{l}\text { Reduce loss rate in } \\
\text { bar processing }\end{array}$ & $\begin{array}{l}\text { - Need to check the exact } \\
\text { amount of bar preparing } \\
\text { for one month order } \\
\text { ahead } \\
\text { - Improve detailed } \\
\text { management skill for } \\
\text { productivity } \\
\text { - Prepare for change- } \\
\text { order } \\
\text { - Quality management in } \\
\text { processed bar }\end{array}$ \\
\hline $\begin{array}{l}\text { Delivery in } \\
\text { site }\end{array}$ & - & $\begin{array}{l}\text { - Proper delivery distance } \\
\text { Reduce delivery cost } \\
\text { - Manage proper amount } \\
\text { for stocking }\end{array}$ \\
\hline Bar check & - & $\begin{array}{l}\text { - Automate the process } \\
\text { in checking amount and } \\
\text { type of bar }\end{array}$ \\
\hline $\begin{array}{l}\text { Moving to } \\
\text { lifting point }\end{array}$ & $\begin{array}{l}\text { Proper schedule } \\
\text { management from } \\
\text { bar processing to } \\
\text { installation } \\
\text { Manage rotten bar } \\
\text { from long stocking }\end{array}$ & $\begin{array}{l}\text { - Reduce stocking } \\
\text { Move to lifting point or } \\
\text { install when delivering }\end{array}$ \\
\hline Installation & $\begin{array}{l}\text { Hard to check bar } \\
\text { types after processing }\end{array}$ & $\begin{array}{l}\text { - Manage interference due } \\
\text { to insufficient space } \\
\text { - Adaptation from } \\
\text { bar processing to bar } \\
\text { assembly in factory }\end{array}$ \\
\hline
\end{tabular}

First of all, it takes a long time to select the subcontractor in both bar and factory processing. In factory processing, it takes a long time to check the initial drawing due to the lack of time and detailed drawing, and the drawing error. Also, the delivery cost and distance are added burdens after bar processing in the factory. Lastly, there is a need to standardize bar processing for productivity.

The loss rate is higher in field processing than in factory processing, and it is difficult to stock and manage bars at the site.

\section{5) Analysis of VAT}

In this study, the steel work process was classified into the selection and contracting of a subcontractor for the steel work, the creation of shop drawings, bar processing, transport, delivery, bar check, moving to the lifting point, and installation. Data regarding the time and number of workers for each step were collected and analyzed in field cases. The table below shows the results of the analysis of the values in the case fields.

Table 9. Value analysis in case sites

\begin{tabular}{c|c|c|c|c|c}
\hline & NVAA(Day) & VAA(Day) & LT(Day) & VAT & Type \\
\hline A & 7.9 & 10 & 17.9 & 0.56 & Field \\
\hline B & 9 & 7 & 16 & 0.44 & Field \\
\hline C & 3.5 & 3 & 6.5 & 0.46 & Factory \\
\hline D & 2.2 & 4.5 & 6.7 & 0.67 & Field \\
\hline E & 4.7 & 4 & 8.7 & 0.46 & Factory \\
\hline F & 6 & 2 & 8 & 0.25 & Factory \\
\hline
\end{tabular}

The results of each case field were divided into factory processing and field production. The average values of each factor were calculated in each case field, as shown in the table below. Table 9 shows that the duration of the sites using factory processing is shorter than that of the sites using field processing, and that the VATs of the sites using factory processing is lower than that using field processing.

Table 10. VAT in field and factory processing of bar

\begin{tabular}{c|c|c|c|c}
\hline & NVAA(Day) & VAA(Day) & LT(Day) & VAT \\
\hline $\begin{array}{c}\text { Field } \\
\text { processing }\end{array}$ & 6.37 & 7.17 & 13.53 & 0.56 \\
\hline $\begin{array}{c}\text { Factory } \\
\text { processing }\end{array}$ & 4.73 & 3.00 & 7.73 & 0.39 \\
\hline
\end{tabular}

As shown in Table 10, factory processing showed lower VAT values compared to field processing. According to Table 10, the VAT of field processing is $0.56(56 \%)$, and that of factory processing is 0.39 (39\%). The VAT of field processing is thus $44 \%$ higher than that of field processing. The reason for this could be that the time spent on the processing and production of bars was short but the percentage of additional NVAAs, such as transport, in-site delivery, and bar check, increased. Although the VAT of factory processing is lower than that of field processing, it does not mean that field processing is more efficient than factory processing. With this result, it can be said that the improvement of NVAA is required in factory processing, especially in the transport and delivery process.

\section{CONCLUSION}

The research team is devoting much effort to optimize the construction management so as to strengthen the competitiveness of the construction work. In particular, the concept of lean construction is being highlighted to minimize the inefficient or non-valuable elements occurring in construction work. In this study, the field processing and factory processing methods were investigated, and which of the two is more efficient in terms of value was determined via analysis. 
This study was conducted targeting bar processing among the ETO materials requiring much time and complex processing for the procurement of materials until they arrive at the field after the order is placed and the contract is sealed. To improve the efficiency, the waste factors occurring in the field processing technique during bar processing were analyzed through the value analysis technique. According to the results of the study, the major waste factors that may occur in field processing are as follows.

The results of the case analysis showed that unnecessary time was spent selecting and contracting a subcontractor for steel work, and that factory processing is more efficient in VAAs such as the creation of shop drawings and processing.

On the other hand, the analysis of the efficiency of the VAAs showed that factory processing has lower efficiency. The reason for this could be that the time spent on VAA works was short compared to the work time for the logistics corresponding to NVAAs such as transport or management of delivery and shipping. In other words, it is thought that factory processing needs to improve the NVAA works and efficiency.

This study focused on bar processing between the field and the factory. In the future, the research team will try to investigate the efficiency improvement in factory processing as the ratio of factory processing should be gradually increased in the near future.

\section{REFERENCES}

Cho Hun-Hee, Park U-Yeol, Kang Tai-Kyung, Park HyunYong, Yun Seok-Heon, Hur Young-Ki., (2007) Analysis of rebar manufacturing system in plant and its facilitate method, Journal of Korea Institute of Construction Engineering and Management, 8,1

Freire, J. and Alarcón, L.F. (2000). "Achieving a Lean Design Process." Proc. Eighth Annual Conference of the International Group for Lean Construction (IGLC-8), 17-19 July, Brighton, UK.

Handfield, R. B., Pannesi, R. T., (1995) Antecedents of leadtime competitiveness in Make-to-order manufacturing firms, International Journal of Production Research, 33, 2, 511-537.

Jan Alarik Elfving., (2003) Exploration of Opportunities to Reduce Lead Times for Engineered-to-Order Products, University of California

Joo Jin-Kyu, Kim Tae-Hui, Kim Sun-Kuk., (2003) A Work Model for Enhancing the Productivity of Rebar Work, Journal of Architecture Institute of Korea, 19, 12

Kim Gwang-Hee, Park Woo-Yull, Kang Kyung-In., (2002) Development of a Improvement System for Quality \& Cost Management of Rebar Work in Korean Building Construction, Journal of Architecture Institute of Korea, 18, 5

Kim Gwang-Ho., (2006) The Root of Rebar Manufacturing in Korea, Taeyeon Machine

Koskela, L., (1999) Management of production in construction: a theoretical view, Proceedings of the Seventh Annual Conference of the International Group for Lean Construction IGLC-7, Berkeley, July 26-28, 1999, pp. 241-252.

Koskela, L., (1992) Application of the New Production Philosophy to Construction, Technical Report No. 72, CIFE Department of Civil Engineering, Stanford University.

Lee Min-Woo, Park Hwan-Pyo, Shin Eun-Young, Kim Kwang-
Hee, Lee Kyo-Sun, Kang Tai-Kyung., (2006) A Basic Study on the Application Possibility of the RFID System in Re-bar Work, Journal of Architecture Institute of Korea, 22, 10

Lee Ung-Kyun, Park Woo-Yull, Kang Kyung-In., (2002) The Study on the Actual Condition of Rebar Work in Korean Building Construction, Proceedings of the Korean Institute of Construction, 2, 2

Mun Jeong-Mun, Kim Chang-Duck., (2002) Productivity Improvement through the Waste Elimination of Construction Process, Journal of Korea Institute of Construction Engineering and Management, 3, 4

Wortmann, J. C., Muntslag, D. R. \& Timmermans, P. J. M., (1997) Customer Driven Manufacturing. London, UK: Chapman \& Hall.

(Received March 6, 2013/Accepted Apri 3, 2013) 